\title{
Arginine Metabolism in Bacterial Pathogenesis and Cancer Therapy
}

\author{
Lifeng Xiong ${ }^{1,+}{ }^{+}$Jade L. L. Teng ${ }^{1,2,3,+}$, Michael G. Botelho ${ }^{4}$, Regina C. Lo ${ }^{5,6}$, \\ Susanna K. P. Lau ${ }^{1,2,3,7, *}$ and Patrick C. Y. Woo $1,2,3,7$,* \\ 1 Department of Microbiology, The University of Hong Kong, Hong Kong, China; lfxiong@hku.hk (L.X.); \\ llteng@hku.hk (J.L.L.T.) \\ 2 Research Centre of Infection and Immunology, The University of Hong Kong, Hong Kong, China \\ 3 State Key Laboratory of Emerging Infectious Diseases, The University of Hong Kong, Hong Kong, China \\ 4 Faculty of Dentistry, The University of Hong Kong, Hong Kong, China; botelho@hku.hk \\ 5 Department of Pathology, The University of Hong Kong, Hong Kong, China; reginalo@pathology.hku.hk \\ 6 State Key Laboratory of Liver Research, The University of Hong Kong, Hong Kong, China \\ 7 Carol Yu Centre for Infection, The University of Hong Kong, Hong Kong, China \\ * Correspondence: skplau@hku.hk (S.K.P.L.); pcywoo@hku.hk (P.C.Y.W.); \\ Tel.: +852-2255-4892 (S.K.P.L. \& P.C.Y.W.); Fax: +852-2255-1241 (S.K.P.L. \& P.C.Y.W.) \\ + These authors contributed equally to this work.
}

Academic Editor: Helmut Segner

Received: 29 December 2015; Accepted: 4 March 2016; Published: 11 March 2016

\begin{abstract}
Antibacterial resistance to infectious diseases is a significant global concern for health care organizations; along with aging populations and increasing cancer rates, it represents a great burden for government healthcare systems. Therefore, the development of therapies against bacterial infection and cancer is an important strategy for healthcare research. Pathogenic bacteria and cancer have developed a broad range of sophisticated strategies to survive or propagate inside a host and cause infection or spread disease. Bacteria can employ their own metabolism pathways to obtain nutrients from the host cells in order to survive. Similarly, cancer cells can dysregulate normal human cell metabolic pathways so that they can grow and spread. One common feature of the adaption and disruption of metabolic pathways observed in bacterial and cancer cell growth is amino acid pathways; these have recently been targeted as a novel approach to manage bacterial infections and cancer therapy. In particular, arginine metabolism has been illustrated to be important not only for bacterial pathogenesis but also for cancer therapy. Therefore, greater insights into arginine metabolism of pathogenic bacteria and cancer cells would provide possible targets for controlling of bacterial infection and cancer treatment. This review will summarize the recent progress on the relationship of arginine metabolism with bacterial pathogenesis and cancer therapy, with a particular focus on arginase and arginine deiminase pathways of arginine catabolism.
\end{abstract}

Keywords: arginine metabolism; arginase; arginine deiminase; bacterial pathogenesis; cancer therapy

\section{Introduction}

Globally, infections and cancers are two of the leading causes of death. Bacterial infections are among the most extensively studied conditions as bacteria have established a broad range of sophisticated strategies to adapt to various environmental stresses and can resist some of the host defenses, such as chemical bactericidal components, phagocytosis (innate), and other immune (adaptive) responses [1,2]. The versatile ability of bacteria to resist host defenses allows bacteria to survive in an infection and promote their own life cycle through replication and spread in host cells [2]. With the recognition of the metabolic differences between normal cells and tumor cells, the therapeutic targeting of the cellular metabolism of cancer cells is an increasing field of research for 
cancer therapy $[3,4]$. The active deprivation of amino acids inside tumor cells, which are auxotrophic for these amino acids, has been recognized as one of the novel approaches for cancer therapy [5]. In this review, we will summarize the recent progress on the relationship of arginine metabolism with bacterial pathogenesis and cancer therapy, with a particular focus on the arginase and arginine deiminase (ADI) pathways of arginine catabolism.

\section{Arginine Metabolism and Bacterial Pathogenesis}

L-arginine is categorized as a conditionally essential amino acid in human beings. This is because it is possible to derive arginine by de novo biosynthesis and absorption from consumed diet [6]. In addition, L-arginine is a metabolically flexible amino acid and is metabolically interconvertible with a range of amino acids such as proline and glutamate. L-arginine is also involved in the synthesis of metabolites such as nitric oxide, creatine, polyamines, agmatine, and metabolites of the urea cycle in the cellular metabolic pathways $[4,7,8]$.

\subsection{Arginase Pathway and Bacterial Pathogenesis}

\subsubsection{Arginase Pathway}

The arginase enzyme and its associated pathway is one arm of arginine catabolism. The arginase pathway hydrolyzes arginine to urea and ornithine, which is then hydrolyzed by ornithine aminotransferase (RocD) and $\Delta$-pyrroline-5-carboxylate dehydrogenase (RocA) respectively, with the production of glutamate [7] (Figure 1). Bacillus subtilis is one of the most studied bacteria for examining the arginase pathway, and is the only pathway of arginine catabolism in B. subtilis, with the production of intermediaries (Figure 1) that can be broken down as a source of nitrogen [9]. In B. subtilis, rocABC [10] and rocDEF [11] operons and the rocG gene [12], are responsible for producing proteins of the arginase pathway. Arginase is encoded by gene rocF in $B$. subtilis and is responsible for catalyzing the first step of the arginase pathway to catabolize arginine [7]. The product from this step (ornithine) is then hydrolyzed by ornithine aminotransferase (RocD) and $\Delta$-pyrroline-5-carboxylate dehydrogenase (RocA), respectively, with the production of glutamate (Figure 1). rocC and rocE encode arginine permeases and RocB probably function as a citrullinase [11,13]. Glutamate can be further catabolized by glutamate dehydrogenase (GDH), which is encoded by rocG gene, with the production of 2-ketoglutarate. Some bacteria employ this pathway to consume arginine and function as the supplier of carbon and/or nitrogen source. For example, if the bacteria also contain the urease system, the byproduct of urea from this pathway could be further catalyzed to ammonia and used as nitrogen source [7]. The genes from the arginase pathway of bacteria and their corresponding products are summarized in Table 1. In addition, their counterparts with similar catabolic function or homologue in mammalian cells (if any) are also listed. 


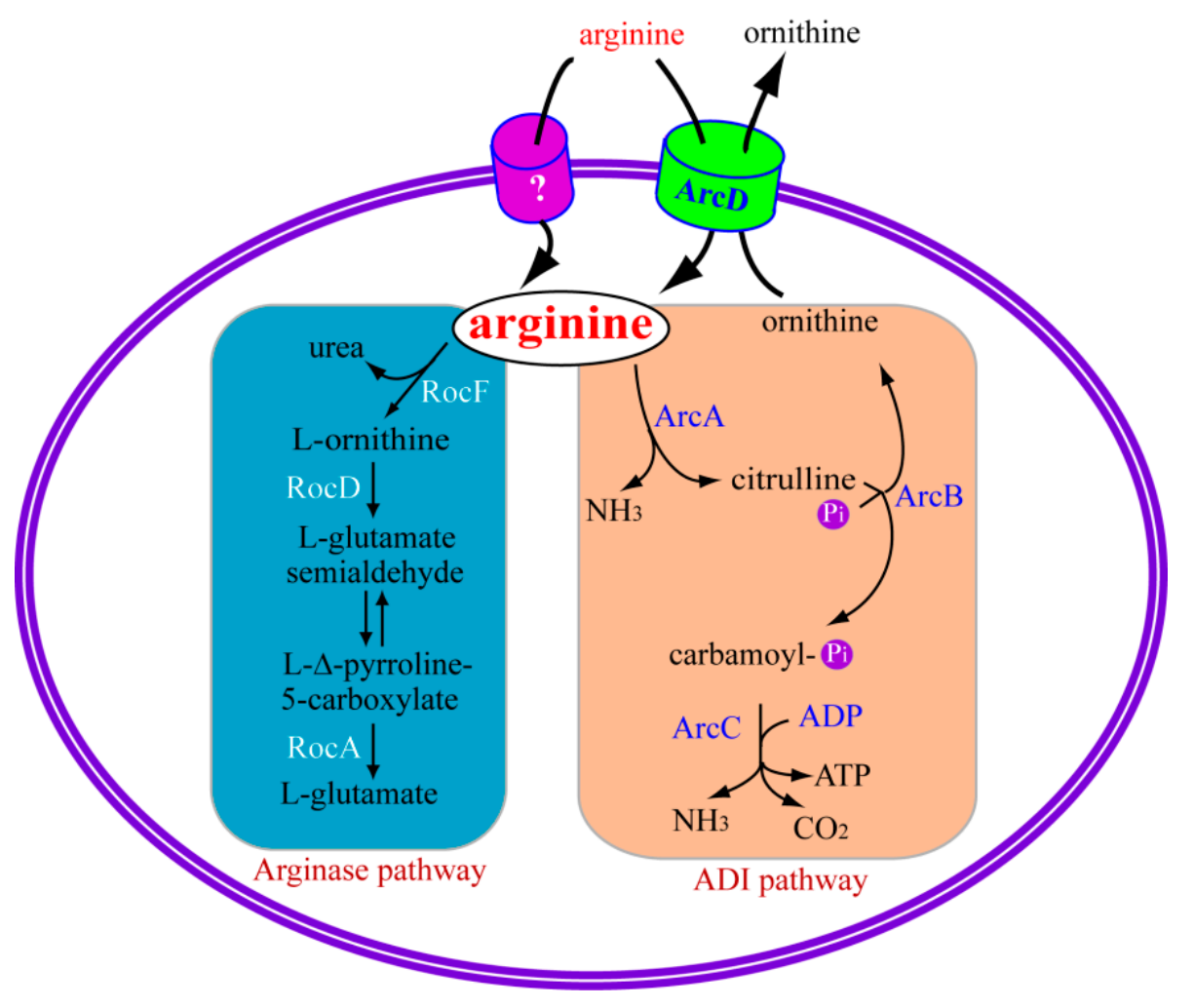

Figure 1. Simplified model for bacterial arginine catabolism by arginase and ADI pathways. In bacteria, arginine could be catalyzed by the arginase pathway (in blue) and/or the ADI pathway (in light salmon). For the arginase pathway, arginine is converted into urea and ornithine, which is subsequently catalyzed into glutamate. The ADI pathway catabolizes arginine to ornithine with the byproducts of ammonia, $\mathrm{CO}_{2}$ and ATP. The produced ornithine could be transported outside and exchange one molecule of arginine in the cell by the arginine-ornithine antiporter (ArcD) located in the bacterial membrane. Arginine may also be transported by some unknown transporters, which are shown by the question mark. RocD: ornithine aminotransferase; RocF: arginase; RocA: $\Delta$-pyrroline-5-carboxylate dehydrogenase; ArcC: carbamate kinase; ArcA: arginine deiminase; ArcB: ornithine carbamoyltransferase; Pi: inorganic phosphate.

Table 1. The genes from arginase and ADI pathway of bacteria and counterparts in mammalian cells with homologue or similar function.

\begin{tabular}{|c|c|c|c|}
\hline $\begin{array}{l}\text { Pathway } \\
\text { (Genes) }\end{array}$ & Products & $\begin{array}{l}\text { Counterparts in Mammalian } \\
\text { Cells (with Similar Function or } \\
\text { Homologue) }\end{array}$ & $\begin{array}{c}\text { Source/ } \\
\text { Reference }\end{array}$ \\
\hline \multicolumn{4}{|c|}{ The arginase pathway } \\
\hline $\operatorname{roc} A$ & $\begin{array}{l}\text { Pyrroline-5-carboxylate } \\
\text { dehydrogenase }\end{array}$ & $\begin{array}{c}\text { Pyrroline-5-carboxylate } \\
\text { dehydrogenase }\end{array}$ & {$[10]$} \\
\hline $\operatorname{roc} B$ & Probable citrullinase & - & {$[13]$} \\
\hline rocC & Arginine permease & Arginine permease-like & {$[11,13]$} \\
\hline rocD & Ornithine aminotransferase (OAT) & Ornithine aminotransferase & [11] \\
\hline roce & Arginine permease & Arginine permease-like & {$[11,13]$} \\
\hline rocF & Arginase & Arginase I and II & {$[11]$} \\
\hline \multicolumn{4}{|c|}{ The ADI pathway } \\
\hline $\operatorname{arc} A$ & Arginine deiminase & Nitric oxide synthase (NOS) & [14-18] \\
\hline $\operatorname{arc} B$ & Ornithine carbamoyltransferase & Ornithine carbamoyltransferase & {$[14,18]$} \\
\hline $\operatorname{arcC}$ & Carbamate kinase & Carbamate kinase-like & {$[15,16]$} \\
\hline $\operatorname{arc} D$ & Arginine-ornithine antiporter & - & [16-18] \\
\hline
\end{tabular}




\subsubsection{Regulation of Arginase Pathway}

Gene expression can be regulated at different stages including transcription, post-transcription, translation, and post-translation. However, the most generally used mechanism of gene regulation in bacteria lies at the transcriptional level [19], and proper transcriptional regulation is crucial for bacteria to respond to varied environmental niches [20]. The transcriptional regulation occurs by binding to the promoter regions in induction or repression manner [19], which could be mediated by transcription factors, environmental stresses, and some other effectors.

Regulation of the arginase pathway has also been well studied in B. subtilis. Both roc $A B C$ and rocDEF operons, encoding enzymes for the arginase pathway, have similar promoter elements $[10,11]$, and their transcription is driven by a specialized protein (sigma factor) encoded by the sigL gene, which has the same function as that of protein sigma 54 in Gram-negative bacteria [21]. In addition, the transcription of $\operatorname{roc} A B C$ and $\operatorname{roc} D E F$ operons promoters is positively regulated by the regulator RocR, which is a transcriptional regulator from the protein family of NtrC/NifA, with a molecular weight of $52 \mathrm{kDa}[7,10,13]$. RocR functions by binding to enhancer-like elements (upstream activating sequences, UASs) of promoter regions of $\operatorname{roc} A B C$ and rocDEF operons [13]. The expression of rocR is negatively autoregulated as the $\mathrm{N}$-terminal part of RocR is an intramolecular repressor domain, and deletion of this domain makes the constitutive expression of the roc operons [11,13]. Furthermore, the expression of $\operatorname{roc} A B C$ and rocDEF operons is also affected by another regulator named $\mathrm{AhrC}[13,22]$. AhrC is a homologous molecule to the arginine transcriptional regulator ArgR in Escherichia coli, which usually binds to the promoter regions of target genes [11,13,22,23]. Similarly, it was shown that AhrC can bind to the promoter region of $r o c A$ in a footprinting experiment [22]. Interestingly, it was proposed in another study that AhrC should function by direct protein-protein interaction with RocR [13]. Besides, the expression of the rocDEF operon was also observed to be induced by the presence of arginine, ornithine, or proline in different environmental niches [11,13].

\subsubsection{The Relationship between the Arginase Pathway and Bacterial Pathogenesis}

Arginine is the common substrate of arginase and inducible type 2 nitric oxide synthase (NOS2 or iNOS), which can be catabolized by arginase to ornithine and urea (Figure 1) or oxidized by iNOS to L-citrulline and nitric oxide (NO) (Figure 2) [24]. Therefore, arginase is well studied for competing with the NOS enzymes for substrate of arginine, thereby limiting NO production by different research groups $[8,24]$. Besides the substrate competition, arginase was also observed to inhibit iNOS expression at the translation level, thereby limiting NO production [8]. NO is a crucial element of innate immunity and is one of the valuable antimicrobials of the host's first line of defense [25,26]. Pathogenic bacteria have developed different strategies targeting arginine for self-preservation. Similar to the arginase of mammalian cells, the arginase produced by bacteria can also compete with iNOS of host cells for the common substrate (arginine), thereby inhibiting the NO production and facilitating evasion of the host defense system $[27,28]$. The competition between arginase and iNOS has been reported to affect the outcome of infection of several pathogenic bacteria by modulating the NO production [29]. Among these pathogenic bacteria, one of the extensively studied examples is Helicobacter pylori, which releases its arginase to downregulate eukaryotic NO production so as to evade the host immune response, thereby serving as a strategy for bacterial survival $[7,28]$. The arginase of $H$. pylori was observed to resist acidic conditions in vitro and in macrophages, thereby reducing antibacterial effects $[28,30]$. Furthermore, arginase was employed by $\mathrm{H}$. pylori to deplete L-arginine in macrophages, thereby limiting NO production and prolonging bacterial survival. Deletion of the rocF gene that is responsible for arginase production significantly increased NO production and thereby decreased the survival of the rocF gene mutant strain in macrophages [28,31]. However, the survival of rocF gene deleted $H$. pylori was not affected in the macrophages from iNOS ${ }^{-/-}$mice, indicating the survival decrease in arginase-deficient $H$. pylori was NO-dependent. In addition, arginase from $H$. pylori also represses the expression of the TCR $\zeta(\mathrm{CD} 3 \zeta$ ) chain, thereby restraining the function of the host $\mathrm{T}$ cells, which can also contribute to bacterial survival during Helicobacter infection [32]. 


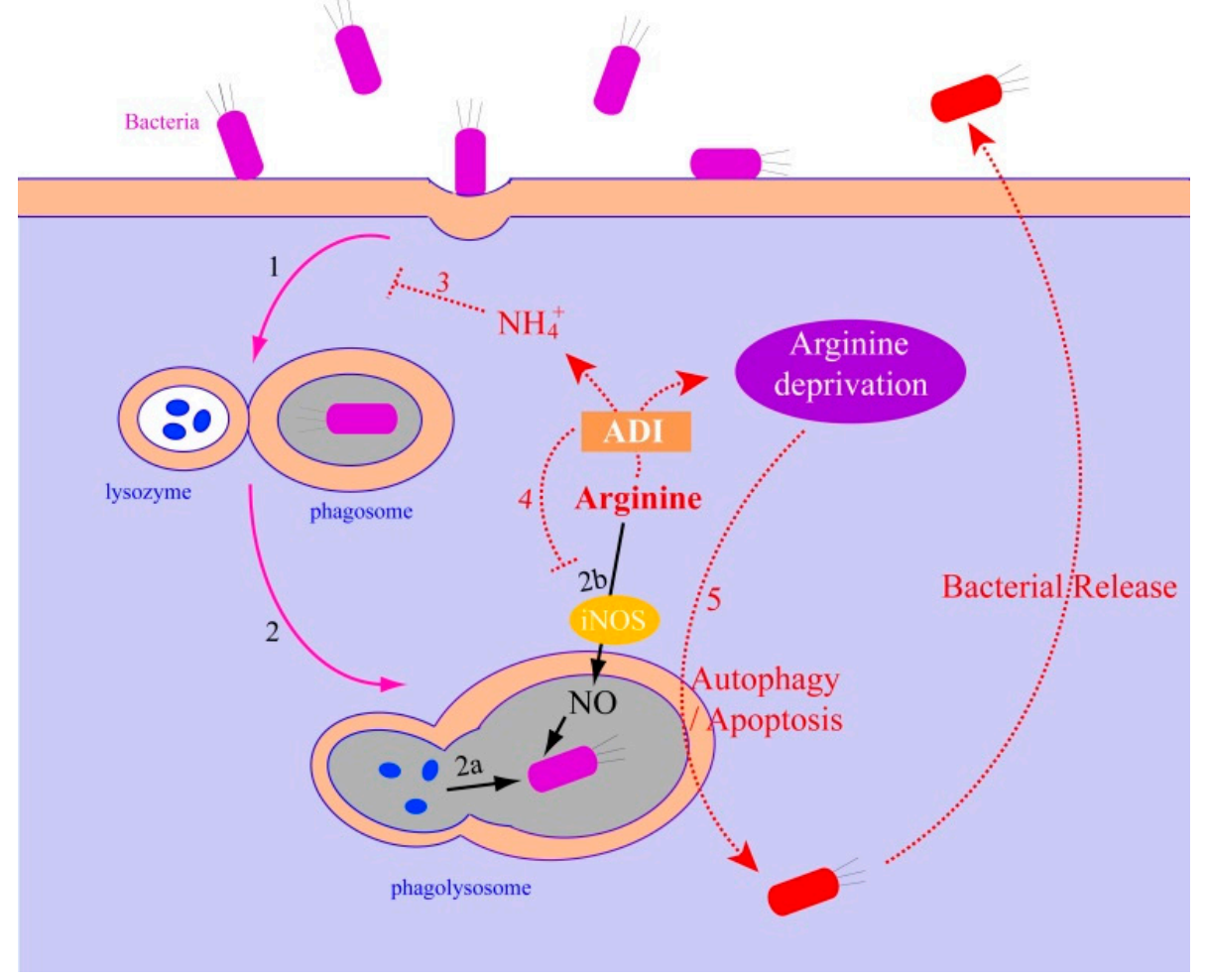

Figure 2. Proposed model for intracellular killing of bacteria by phagocyte and bacterial defense strategies against phagocytosis. Bacteria could be engulfed by a phagocyte into the phagosome (1), followed by fusion with a lysozyme to form a phagolysosome (2), being killed by varied strategies like $\mathrm{pH}$ decrease, enzymes (solid blue oval) release (2a), and production of antimicrobial NO by iNOS (2b). We propose that the bacteria containing ADI pathway genes may employ this pathway to defend these killing strategies in the following ways: firstly, the production of ammonia could probably raise the cytoplasmic $\mathrm{pH}$, thereby inhibiting the formation of phagolysosome (3); secondly, the ADI pathway competes with iNOS for the common substrate (arginine), thereby reducing NO production (4); thirdly, arginine depletion would also activate the autophagy and/or apoptosis pathways, like that in cancer cells (Figure 3), to induce programmed cell death and release bacteria (5).

H. pylori were found to upregulate arginase (arginase II) in RAW 264.7 macrophage cell lines, in a mouse model, and in human gastritis tissues. This upregulation was found to induce apoptosis. The action of arginase on arginine can produce an intermediary spermine, with the help of ornithine decarboxylase and spermine synthase. This is used by $H$. pylori to repress the expression of pro-inflammatory cytokines and iNOS, thereby preventing the antimicrobial effects of NO and the immune response in stimulated macrophages [33]. Of note, it was shown that host arginase (arginase II), which was upregulated to reduce NO production, can increase bacterial survival in Salmonella-infected macrophages [34]. Arginase has also been shown to be involved in bacterial infection caused by Mycobacterium tuberculosis [35,36], parasitic infection caused by Trypanosoma cruzi [37], and fungal infection caused by Candida albicans [38], implying the critical role of arginase for other infections. 


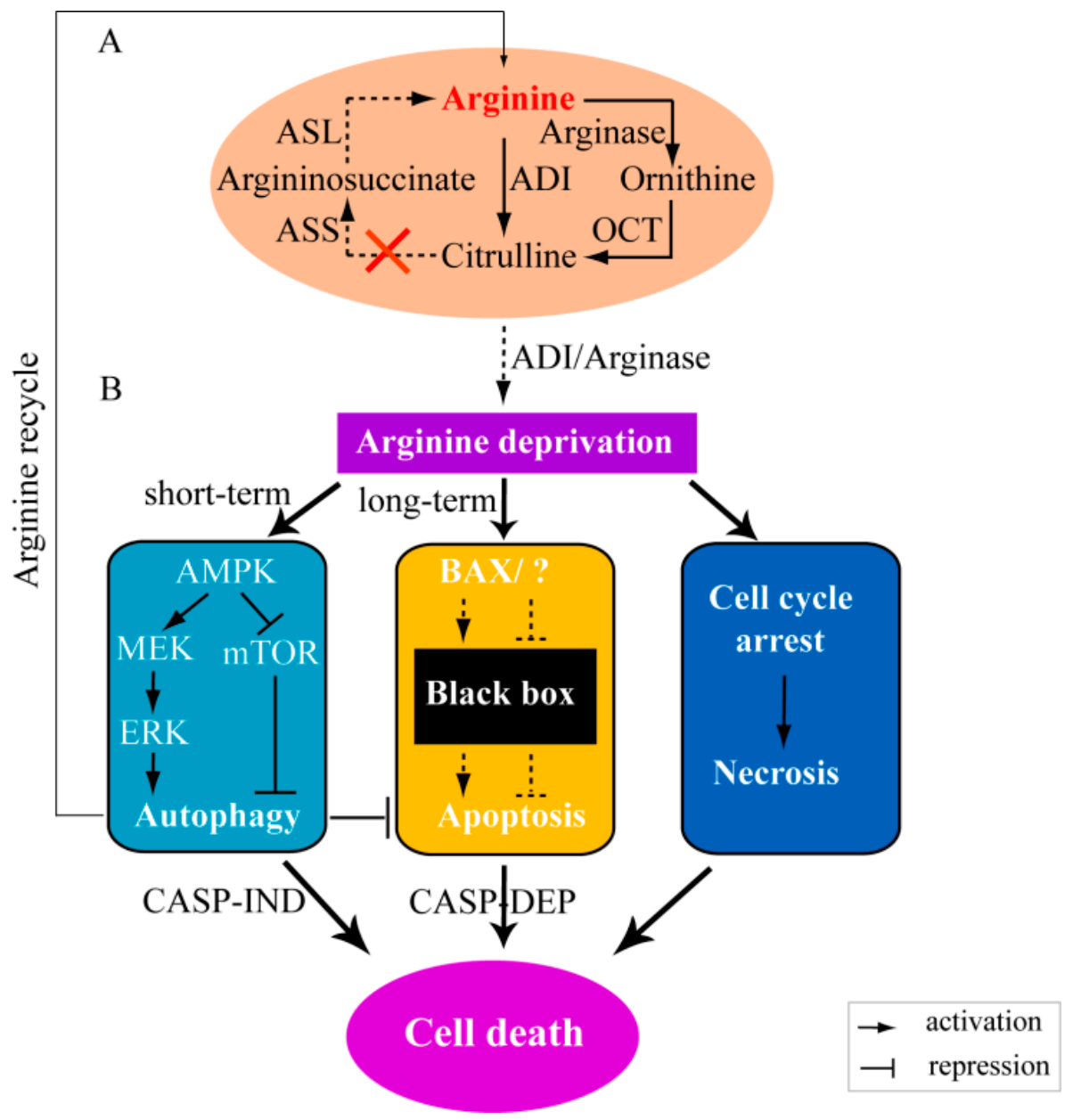

Figure 3. Schematic representation of argininosuccinate synthetase (ASS)-negative cell death induced by arginine deprivation. In ASS-negative cells, arginine cannot synthesize so arginine depletion by ADI or arginase would induce a quick response of cell autophagy by the mammalian Target of Rapamycin (mTOR) or MEK-ERK pathway. Autophagy could recycle limited arginine and prevent apoptosis as a survival response in the short term. Instead, in long-term arginine deprivation, autophagy would contribute to caspase-independent (CASP-IND) cell death and caspase dependent (CASP-DEP) apoptosis could also happen. The dashed lines ( $\cdots \rightarrow$ and $\cdots . . \cdot)$ means the reactions are dependent on the availability of enzymes (panel A) or the reactions have not yet confirmed by experiments (panel B). MEK: mitogen-activated protein kinase, also known as extracellular signal-regulated kinase kinase; ERK: extracellular signal-regulated kinase.

\subsection{Arginine Deiminase Pathway and Bacterial Pathogenesis}

\subsubsection{Arginine Deiminase Pathway}

Arginine metabolism via the ADI pathway is well established to be broadly present in a number of microorganisms and enables them to adapt to hostile environmental niches and host defenses [14-17,39,40]. As one of the most important arginine catabolism pathways, the ADI pathway is a multi-enzyme pathway encoded by $\operatorname{arc}$ operons genes named $\operatorname{arc} A, \operatorname{arc} B$, and $\operatorname{arcC}[15,39]$, which hydrolyze arginine to ornithine, with the byproducts of ammonia, $\mathrm{CO}_{2}$ and ATP. Generally, arginine is first catabolized to citrulline by $\operatorname{arcA-encoded~ADI,~which~is~further~hydrolyzed~to~}$ ornithine and carbamoyl phosphate via an $\operatorname{arcB}$-encoded catabolic ornithine carbamoyltransferase (OTC). Finally, a phosphate is relocated from carbamoyl phosphate to adenosine diphosphate (ADP), by an $\operatorname{arcC}$-encoded enzyme named carbamate kinase (CK), with the production of ammonia, carbon 
dioxide, and ATP. The production of ammonia by the ADI pathway could further produce $\mathrm{NH}_{4}^{+}$and thus increase the cytoplasmic $\mathrm{pH}$, thereby protecting the bacteria from being killed by the hostile acidic conditions [15]. Furthermore, the production of ATP can provide energy for bacteria to pump cytoplasmic protons and maintain cytosolic $\mathrm{pH}$ homeostasis [15]. Another element of this pathway, an arginine-ornithine antiporter ( $\mathrm{ArcD}$ ) encoding by $\operatorname{arcD}$, could transport ornithine out and exchange a molecule of arginine into the cell (Figure 1) $[14,15,18]$. The genes from the ADI pathway of bacteria and corresponding products are summarized in Table 1. Their counterparts with similar catabolic function or homologue in mammalian cells (if any) are also listed.

\subsubsection{Regulation of Arginine Deiminase Pathway}

As stated in Section 2.1.2, the most extensively studied regulatory mechanism of the ADI pathway also lies at the transcriptional level, which is mediated by the transcriptional regulator ArgR $[9,15,17]$. ArgR could be derived from two different protein families: ArgR/AhrC [41-43] and AraC $/$ XylS $[9,44,45]$. Irrespective of the family origin, ArgR proteins generally elicit their regulatory role by binding to the ARG operator (ARG box) located in the arc operon promoter [46,47], via a conserved helix-turn-helix motif in the C-terminal of ArgR [48]. Generally, ArgR regulator activates the expression of ADI pathway genes in their individual bacteria [15,17,45,46,49]; the only exception is the ArgR of Laribacter hongkongensis, a novel beta proteobacterium associated with gastroenteritis [50,51], which has been illustrated to have dual regulatory functions on two adjacent arc operons within L. hongkongensis [52].

Besides the transcriptional regulation by ArgR, ADI pathway genes are also affected by a variety of environmental stresses. Firstly, the expression of ADI pathway genes are established to be activated by anaerobicity in different bacteria [53], such as Pseudomonas aeruginosa, Bacillus licheniformis, and Streptococcus suis, mediated by transcriptional regulators from the protein family of Crp/Fnr [54-56]. In enteric anaerobic bacteria, regulators from the Crp/Fnr family recognize conserved Crp/Fnr DNA-binding sites located in the arc operon promoter [57,58], enabling them to function as a transcriptional activator. Furthermore, carbon catabolite repression (CCR) has also been demonstrated on the expression of ADI pathway genes in various bacteria $[40,56,59,60]$. In these bacteria, the expression of arc operon genes is repressed by glucose and the repression is usually mediated by a catabolite control protein A (CcpA) or ArcR, the transcriptional regulators belonging to the Crp/Fnr family $[40,56,59]$, by the binding of regulatory proteins to the cis-acting catabolite response elements (cre) located in the promoter regions [61]. Moreover, bacteria have to survive and inhabit diverse environmental niches or hosts, so they have complex regulatory mechanisms to sense and respond to different environmental stresses; for example, it has been shown that the expression of the ADI pathway of S. suis and L. hongkongensis occurs at varied temperatures, allowing better adaptation and survival in different environments [52,62].

\subsubsection{The Relationship between the ADI Pathway and Bacterial Pathogenesis}

Due to the great importance of arginine metabolic functions, the ADI pathway has been demonstrated to be necessary for bacterial survival under acidic conditions and important for bacterial virulence in varied bacteria $[14-17,56,63,64]$. The ammonia produced by the ADI pathway can neutralize the cytoplasmic $\mathrm{pH}$ and protect the cell from the potentially lethal effects of acidic extracellular environments $[15,16,65]$. Furthermore, ADI was demonstrated to be required for Streptococcus pyogenes to invade and survive inside epithelial cells, and necessary for the intracellular survival of L. hongkongensis in macrophage cell lines [14,16]. Additionally, mutation of ADI gene has been shown to reduce the survival of Listeria monocytogenes in the spleen of a mouse infection model [15]. Importantly, the ADI of Salmonella enterica serovar Typhimurium was recently established as a virulence factor [17]. It was demonstrated that the expression of the ADI pathway genes of $S$. Typhimurium was elevated after infecting macrophages cell lines, and disruption of ADI gene significantly reduced the 
bacterial replication in murine macrophages and attenuated the bacterial virulence in a mouse model, when compared to the wild-type strain [17].

Although studied extensively, the precise mechanism by which the ADI pathway enhances intracellular survival of bacteria and even their replication within macrophages is still unclear [16]. However, it is believed that there is some connection between phagocytosis and the ADI pathway $[16,17,66]$. As an important defense strategy in innate immunity, phagocytosis has always been employed by our immune system to initiate the innate immune response and destroy infectious microorganisms [67]. In the process of phagocytosis, bacteria are enclosed in the phagosome [68,69], which would undergo maturation and fuse with the lysosome, to form the phagolysosome [70], where the $\mathrm{pH}$ drops as low as 4.4-4.7 [71-74]. Since the ADI pathway has the property of increasing the cytoplasmic $\mathrm{pH}$, it would be employed to protect bacteria from the potentially lethal effect of acidic extracellular environments [15]. The ADI pathway can also protect bacteria from being killed in the phagolysosome, via arresting the $\mathrm{pH}$ decrease (Figure 2), thereby preventing the phagosome and lysosome from fusing. Bacteria ingested by phagocytes can be degraded in phagolysosomes in different ways, including proteolytic enzymes like lysozymes, cationic proteins, and production of antimicrobial products $[17,75]$. Of these antimicrobials, NO is synthesized from arginine by iNOS, and the availability of arginine is one of the rate-limiting factors for intracellular NO production [76-78]. As the ADI pathway consumes arginine as a substrate, it appears that bacteria can use the ADI pathway to exhaust arginine in the host cell. This will reduce NO production, avoid NO-mediated killing in the phagocytes, and increase bacterial survival (Figure 2). However, a study on $S$. Typhimurium excluded this possibility as the wild-type and ADI mutant strains have similar levels of NO production after infection in macrophages [17]. More studies are needed to investigate other mechanisms in further bacteria [2]. Remarkably, recombinant ADI (rADI) protein was employed as the neuroprotective protein and was capable of blocking iNOS-induced NO production in neuronal cells as the neuroprotective protein [79]; whether pathogenic bacteria would employ this strategy to escape from phagocytosis killing warrants further investigation. There could also be many other possibilities. For example, one proposed strategy is that the production of ATP in the process of ADI pathway enables bacteria to provide energy for $\mathrm{F}_{1} \mathrm{~F}_{\mathrm{O}}$-ATPase to pump cytoplasmic protons and so maintain cytosolic $\mathrm{pH}$ homeostasis under acidic environments. Similar strategies have been employed by many pathogenic bacteria to survive within acidified phagosomes [80-83].

\section{Arginine Metabolism and Cancer Therapy}

Disorder of cellular metabolism has been accepted as one of the critical marks for cancer production and expansion [3,4]; this has stimulated research on cancer metabolism and both the basic science and clinical treatment of cancer $[3,84]$. The metabolic differences between normal cells and tumor cells have provided opportunities for developing novel approaches for the diagnosis and treatment of cancer with higher specificity and lower toxicity than conventional cancer therapies like radiation and chemotherapy $[4,85,86]$. Of note, it is becoming clear that amino acid metabolic pathways could be chemotherapeutic targets for cancer therapy, as cancer cells need abnormal quantities of varied amino acids for their distinct metabolism to maintain high proliferative rates and resist some cell death signals [87]. Consequently, the deprivation of amino acids needed by cancer cells to survive has been recognized in the field of cancer therapy for a long time [5], especially for some cancers that are auxotrophic for specific non-essential amino acids $[4,6]$.

\subsection{Arginine Deprivation and Cancer Therapy}

The relationship between arginine and cancer has been recognized for many years [88]. Generally, de novo biosynthesis of arginine is from the precursor argininosuccinate, which in turn is produced from citrulline; this is facilitated by the enzymes argininosuccinate lyase (ASL) and ASS, respectively (Figure 3) [4,89]. ASS is the rate-limiting biosynthetic enzyme for intracellular arginine synthesis in different cells $[86,89]$; however, in some tumor cells it is reduced or even absent, like hepatocellular 
carcinoma (HCC), mesotheliomas, renal cell carcinoma, prostate cancers, and the majority of melanoma [90-92] (Table 2). These ASS-negative tumor cells are auxotrophic (dependent on uptake of extracellular arginine) for arginine and thus are very sensitive to arginine deprivation $[4,85,89]$. The clinical relevance of arginine metabolism in cancers was illustrated by the association of reduced ASS and more aggressive clinical behavior in pancreatic cancer [93]. In addition, evaluation of ASS1 levels in clinical samples of acute myeloid leukemia is deemed a promising direction for identifying patients who would be more sensitive to arginine deprivation therapy [94]. Consequently, arginine deprivation by arginine-degrading enzymes has been used as a therapy for selective tumor cell death while not harming normal cells [89]. However, only ADI and arginase are the commonly investigated arginine-degrading enzymes in basic and clinical research. This is because the other arginine-degrading enzymes have limitations, such as low affinity with arginine, higher optimal $\mathrm{pH}$, and poor stability $[6,85,88]$.

Table 2. Common cancer cells with reduced or absent ASS production.

\begin{tabular}{cc}
\hline Cancer Cell Types & Source or Reference \\
\hline Melanoma & {$[5,85,90,93,95-100]$} \\
Breast cancer cells & {$[89]$} \\
Prostate cancer cells & {$[4,86,90,101,102]$} \\
Lymphoma & {$[89,103,104]$} \\
Hepatocellular carcinoma (HCC) & {$[5,90,93,98,100,105-107]$} \\
Pancreatic cancer cells & {$[91,93,108]$} \\
Leukemia & {$[94,109-111]$} \\
Glioma & {$[89,112]$} \\
Mesothelioma cell lines & {$[5,113]$} \\
Renal cell carcinoma & {$[4,93,114]$} \\
Lung cancer & {$[93,115]$} \\
\hline
\end{tabular}

Arginase is responsible for hydrolyzing arginine to ornithine, which in turn can be converted to citrulline by Ornithine carbamoyl transferase (OCT), thereby depleting the arginine in the arginine auxotrophic cancer cells (Figures 1 and 3). There are two subtypes of arginase in humans (arginase I and arginase II). Arginase I is mainly found in the liver and is considered the more efficient subtype and used more commonly in research [6]. Compared with the arginase of bacteria, the arginase from human sources has the advantage of low immunogenicity for use in vivo. However, it has been observed to have a low affinity with arginine in vitro [4] and requires a higher $\mathrm{pH}$ than physiological conditions for optimal activity (up to 9.5) [116], which limits its clinical effectiveness in cancer therapy. To overcome these, recombinant human arginase (rhArg-PEG) has been produced by linking polyethylene glycol (PEG) to the arginase, which increases its affinity with arginine and improves the half-life in vivo [117]. In addition, the replacement of $\mathrm{Mn}^{2+}$ with $\mathrm{Co}^{2+}$ in the active site of arginase can reduce the optimal $\mathrm{pH}$ of recombinant human arginase (rhArg1) to as low as 7.5 and this metal ion replacement also enhances rhArg1 cytotoxicity in hepatoma cancer cell lines [118]. Recently, other recombinant human arginase (rhArg1-Fc) has been produced by ligating Fc fragment of human IgG1 to arginase I; this greatly increases the half-life, inhibits cell proliferation, and impairs cellular migration of different tumor cell lines both in vitro and in vivo [6,119].

Arginine deiminase is another well-studied arginine-depriving enzyme and this degrades arginine to citrulline, which can be recycled back to arginine by ASS and ASL in many cell types but not in ASS-negative cancer cells (Figure 3) [88,120]. The application of ADI for anti-tumor therapy in cancer cell lines and animal models was demonstrated over two decades ago [121,122]. As ADI is not produced in mammals, ADI protein for research is most commonly derived from Mycoplasma arginini [6]. However, because of its short half-life and high antigenicity, ADI is linked with PEG (ADI-PEG20) and has been used for research and clinical use $[4,123]$. This has been observed to have significantly reduced antigenicity, increased half-life [123], and high affinity with arginine (about 300-fold that 
of arginase under physiological $\mathrm{pH})[85,101,124]$. Because of its efficacy, it has been widely used in clinical trials for anti-cancer treatment $[105,106,125]$. Of note, a recent study of neuroblastoma cells has shown ADI-PEG20 to have potential for treating iNOS-mediated neurodegenerative diseases [126]. Importantly, it was reported that ADI-PEG20 treatment in mesothelioma patients can produce anti-ADI-PEG20 neutralizing antibodies by the fourth week, thereby resisting drug usage; further drug optimization is still needed to reduce ADI treatment's immunogenicity, replace it with human recombinant arginase I, and combine with various drugs [3,127,128].

\subsection{Molecular Mechanisms of Arginine Depletion for Cancer Therapy}

\subsubsection{Arginine Deprivation Induces Autophagy in ASS-negative Cells}

Arginine is an essential amino acid in ASS-negative tumor cells (Table 2) as these arginine auxotrophic cells lack the ASS enzyme (Figure 3) responsible for generating arginine from citrulline and therefore have to uptake extracellular arginine. It has been demonstrated that arginine depletion in these cells causes nutritional deprivation and consequently induces autophagy, so that application of arginine deprivation enzymes has been undertaken for cancer therapy $[5,85,101]$. Autophagy is a highly regulated cellular pathway in which the constituents are sequestrated into double-membrane compartments (known as autophagosomes) and fused with lysosomes for degradation [129-131]. This process is the principal catabolic pathway to nutrient starvation $[86,89,129,132]$. Autophagy can be activated by a range of pathways, one of which is the mTOR pathway.

During nutritional deprivation, the mTOR pathway is inhibited; this in turn inactivates some of the non-essential energy consuming intracellular processes to preserve cell viability. This protective process is an extensively investigated pathway for activating autophagy and can be triggered by arginine depletion $[5,85,101]$. ADI treatment can cause arginine deprivation of tumor cells, which in turn activates AMP-activated protein kinase (AMPK) $[5,101]$. This molecule is recognized to inhibit mTOR activity via energy/nutrient sensing $[109,133,134]$ (Figure 3) and so induce autophagy. Furthermore, the activated AMPK induced by ADI treatment could also activate the MEK-ERK pathway, which has been reported to be involved in autophagy by regulating Beclin 1 via noncanonical pathway [135], suggesting that the MEK-ERK signaling pathway was also activated to induce autophagy by arginine depletion [85,101]. Together, arginine deprivation by ADI treatment in ASS-negative cancer cells activates AMPK, which further represses the mTOR activation and stimulates the MEK-ERK pathway, thereby inducing autophagy activation. This is a survival strategy for cancer cells as the limited arginine can be recycled and provide protection for other cells [85].

Apart from autophagy, arginine metabolism was demonstrated to modulate chemosensitivity of cancer cells. In particular, ADI reinforced the effects of gemcitabine on pancreatic cancer cells [93]. This was achieved through regulation of cell cycle progression, the caspase system, as well as the NF-KB pathway.

\subsubsection{Arginine Deprivation Prompts Cell Death in ASS-negative Cells}

Arginine deprivation has also been reported to induce apoptosis and cause cell death in ASS-negative tumor cell lines, including human lymphoblastic cell lines, mesothelioma cells, melanoma cell lines, prostate cancer cell lines, and breast cancer $[5,89,95,101,113,136,137]$. Although the signaling pathway responsible for apoptosis is still not clear, it is recognized that the apoptosis induced by arginine deprivation could be activated via caspase-dependent and/or independent pathways [85,102]. Szlosarek et al. showed that arginine depletion in ASS-negative mesothelioma cells induced apoptosis via $\mathrm{Bcl}-2$-associated $\mathrm{X}$ protein (BAX) activation and mitochondrial inner membrane depolarization [113]. Importantly, excessive autophagy could be cytotoxic and also cause cell death (program type II or caspase-independent cell death) $[86,89,138]$. Kim et al. observed that autophagy induced by arginine depletion in ASS-negative cells could lead to apoptotic cell death in a caspase-independent manner at four days after ADI treatment [101]. In ASS1-deficient breast cancer cells, prolonged 
autophagy activated by ADI treatment impaired mitochondrial bioenergetics and integrity by inducing mitochondrial oxidative stress, and finally caused cell death, indicating the relationship of the cytotoxic autophagy arisen by mitochondrial dysfunction with cell death [89]. Furthermore, Changou et al. observed that mitochondrial damage played a central role in new atypical cell death induced by arginine starvation in the late phase of autophagy. This can lead to reactive oxygen species generation, DNA leakage, chromatin autophagy, and finally cell death [86]. Remarkably, the recombinant human arginase (rhArg) treatment restrains the proliferation of mammalian melanoma in vitro and in vivo and causes cell death induced by apoptosis [96]. The reason why rhArg affects cell proliferation is that the rhArg can induce the cell cycle arrest at both of G2/M and S phase. Similarly to arginine depletion caused by ADI treatment, the cell cycle arrest caused by rhArg also upregulates the caspase expression, thereby inducing apoptosis [96].

The processes of autophagy and apoptosis are related in ASS-negative cells. In the early stage of nutrient deficiency, autophagy will be triggered to recycle limited arginine and preserve the tumor cell and this will have an inhibitory effect on apoptosis. However, when the cells undergo arginine depletion for a longer time and autophagy cannot provide arginine anymore, the cells will undergo caspase-independent apoptosis. Meanwhile, caspase-dependent apoptosis could also be activated by ADI treatment via some other signaling pathways, for example BAX activation (Figure 3). In addition to the arginine deprivation-caused cell death by autophagy and apoptosis pathways, cell death induced by necrosis was also observed in acute myeloid leukemia (AML) treated with pegylated (PEG) recombinant human arginase (BCT-100) [110]. BCT-100 treatment in AML was observed to reduce the arginine concentration (in vitro and intracellular) and AML blasts. Furthermore, the arginine depletion of BCT-100 treatment significantly arrested AML proliferation and the cell cycle, resulting in cell death of necrosis, including cell membrane permeabilization and organelle enlargement [110]. Interestingly, the cell cycle arrest in AML did not induce cell apoptosis, autophagy, and rapid production of reactive oxygen species.

\section{Conclusions}

Our recent findings on the biochemical pathways of arginine metabolism and their regulation in bacteria and cancer cells have not only improved our knowledge of the pathogenesis of bacterial pathogens and cancer metabolism, but may also result in specific anti-bacterial and anti-cancer therapies. Further work in these areas is warranted to improve our armory of strategies against these two common groups of diseases affecting human health.

Acknowledgments: This work was partly supported by the Strategic Research Theme Fund and Small Project Funding Scheme, University of Hong Kong.

Author Contributions: Lifeng Xiong and Patrick C. Y. Woo conceived the paper. Lifeng Xiong wrote the paper. Jade L. L. Teng, Michael G. Botelho, Regina C. Lo, Susanna K. P. Lau, and Patrick C. Y. Woo corrected the manuscript. All authors read and approved the final manuscript.

Conflicts of Interest: The authors declare no conflict of interest.

\section{References}

1. Egan, S.; Fernandes, N.D.; Kumar, V.; Gardiner, M.; Thomas, T. Bacterial pathogens, virulence mechanism and host defence in marine macroalgae. Environ. Microbiol. 2014, 16, 925-938. [CrossRef] [PubMed]

2. Hornef, M.W.; Wick, M.J.; Rhen, M.; Normark, S. Bacterial strategies for overcoming host innate and adaptive immune responses. Nat. Immunol. 2002, 3, 1033-1040. [CrossRef] [PubMed]

3. Phillips, M.M.; Sheaff, M.T.; Szlosarek, P.W. Targeting arginine-dependent cancers with arginine-degrading enzymes: Opportunities and challenges. Cancer Res. Treat. 2013, 45, 251-262. [CrossRef] [PubMed]

4. Kuo, M.T.; Savaraj, N.; Feun, L.G. Targeted cellular metabolism for cancer chemotherapy with recombinant arginine-degrading enzymes. Oncotarget 2010, 1, 246-251. [CrossRef] [PubMed]

5. Feun, L.; You, M.; Wu, C.J.; Kuo, M.T.; Wangpaichitr, M.; Spector, S.; Savaraj, N. Arginine deprivation as a targeted therapy for cancer. Curr. Pharm. Des. 2008, 14, 1049-1057. [CrossRef] [PubMed] 
6. Qiu, F.; Huang, J.; Sui, M. Targeting arginine metabolism pathway to treat arginine-dependent cancers. Cancer Lett. 2015, 364, 1-7. [CrossRef] [PubMed]

7. Lu, C.D. Pathways and regulation of bacterial arginine metabolism and perspectives for obtaining arginine overproducing strains. Appl. Microbiol. Biotechnol. 2006, 70, 261-272. [CrossRef] [PubMed]

8. Morris, S.M., Jr. Arginine metabolism: Boundaries of our knowledge. J. Nutr. 2007, 137, 1602s-1609s. [PubMed]

9. Maghnouj, A.; de Sousa Cabral, T.F.; Stalon, V.; Vander Wauven, C. The $\operatorname{arcABDC}$ gene cluster, encoding the arginine deiminase pathway of Bacillus licheniformis, and its activation by the arginine repressor ArgR. J. Bacteriol. 1998, 180, 6468-6475. [PubMed]

10. Calogero, S.; Gardan, R.; Glaser, P.; Schweizer, J.; Rapoport, G.; Debarbouille, M. RocR, a novel regulatory protein controlling arginine utilization in Bacillus subtilis, belongs to the NtrC/NifA family of transcriptional activators. J. Bacteriol. 1994, 176, 1234-1241. [PubMed]

11. Gardan, R.; Rapoport, G.; Debarbouille, M. Expression of the rocDEF operon involved in arginine catabolism in Bacillus subtilis. J. Mol. Biol. 1995, 249, 843-856. [CrossRef] [PubMed]

12. Belitsky, B.R.; Sonenshein, A.L. An enhancer element located downstream of the major glutamate dehydrogenase gene of Bacillus subtilis. Proc. Natl. Acad. Sci. USA 1999, 96, 10290-10295. [CrossRef] [PubMed]

13. Gardan, R.; Rapoport, G.; Debarbouille, M. Role of the transcriptional activator RocR in the arginine-degradation pathway of Bacillus subtilis. Mol. Microbiol. 1997, 24, 825-837. [CrossRef] [PubMed]

14. Xiong, L.; Teng, J.L.; Watt, R.M.; Kan, B.; Lau, S.K.; Woo, P.C. Arginine deiminase pathway is far more important than urease for acid resistance and intracellular survival in Laribacter hongkongensis: A possible result of arc gene cassette duplication. BMC Microbiol. 2014, 14. [CrossRef] [PubMed]

15. Ryan, S.; Begley, M.; Gahan, C.G.; Hill, C. Molecular characterization of the arginine deiminase system in Listeria monocytogenes: Regulation and role in acid tolerance. Environ. Microbiol. 2009, 11, 432-445. [CrossRef] [PubMed]

16. Degnan, B.A.; Fontaine, M.C.; Doebereiner, A.H.; Lee, J.J.; Mastroeni, P.; Dougan, G.; Goodacre, J.A.; Kehoe, M.A. Characterization of an isogenic mutant of Streptococcus pyogenes Manfredo lacking the ability to make streptococcal acid glycoprotein. Infect. Immun. 2000, 68, 2441-2448. [CrossRef] [PubMed]

17. Choi, Y.; Choi, J.; Groisman, E.A.; Kang, D.H.; Shin, D.; Ryu, S. Expression of STM4467-encoded arginine deiminase controlled by the STM4463 regulator contributes to Salmonella enterica serovar Typhimurium virulence. Infect. Immun. 2012, 80, 4291-4297. [CrossRef] [PubMed]

18. Fulde, M.; Willenborg, J.; Huber, C.; Hitzmann, A.; Willms, D.; Seitz, M.; Eisenreich, W.; Valentin-Weigand, P.; Goethe, R. The arginine-ornithine antiporter ArcD contributes to biological fitness of Streptococcus suis. Front. Cell. Infect. Microbiol. 2014, 4. [CrossRef] [PubMed]

19. Herrgard, M.J.; Covert, M.W.; Palsson, B.O. Reconstruction of microbial transcriptional regulatory networks. Curr. Opin. Biotechnol. 2004, 15, 70-77. [CrossRef] [PubMed]

20. Huffman, J.L.; Brennan, R.G. Prokaryotic transcription regulators: More than just the helix-turn-helix motif. Curr. Opin. Struct. Biol. 2002, 12, 98-106. [CrossRef]

21. Debarbouille, M.; Martin-Verstraete, I.; Kunst, F.; Rapoport, G. The Bacillus subtilis sigL gene encodes an equivalent of sigma 54 from gram-negative bacteria. Proc. Natl. Acad. Sci. USA 1991, 88, 9092-9096. [CrossRef] [PubMed]

22. Klingel, U.; Miller, C.M.; North, A.K.; Stockley, P.G.; Baumberg, S. A binding site for activation by the Bacillus subtilis AhrC protein, a repressor/activator of arginine metabolism. Mol. Gen. Genet. 1995, 248, 329-340. [CrossRef] [PubMed]

23. North, A.K.; Smith, M.C.; Baumberg, S. Nucleotide sequence of a Bacillus subtilis arginine regulatory gene and homology of its product to the Escherichia coli arginine repressor. Gene 1989, 80, 29-38. [CrossRef]

24. Wu, G.; Morris, S.M., Jr. Arginine metabolism: Nitric oxide and beyond. Biochem. J. 1998, 336, 1-17. [CrossRef] [PubMed]

25. Bogdan, C. Of microbes, macrophages and nitric oxide. Behring Inst. Mitt. 1997, 99, 58-72. [PubMed]

26. Bogdan, C.; Rollinghoff, M.; Diefenbach, A. The role of nitric oxide in innate immunity. Immunol. Rev. 2000, 173, 17-26. [CrossRef] [PubMed]

27. Boucher, J.L.; Moali, C.; Tenu, J.P. Nitric oxide biosynthesis, nitric oxide synthase inhibitors and arginase competition for L-arginine utilization. Cell. Mol. Life Sci. 1999, 55, 1015-1028. [CrossRef] [PubMed] 
28. Gobert, A.P.; McGee, D.J.; Akhtar, M.; Mendz, G.L.; Newton, J.C.; Cheng, Y.; Mobley, H.L.; Wilson, K.T. Helicobacter pylori arginase inhibits nitric oxide production by eukaryotic cells: A strategy for bacterial survival. Proc. Natl. Acad. Sci. USA 2001, 98, 13844-13849. [CrossRef] [PubMed]

29. Das, P.; Lahiri, A.; Lahiri, A.; Chakravortty, D. Modulation of the arginase pathway in the context of microbial pathogenesis: A metabolic enzyme moonlighting as an immune modulator. PLoS Pathog. 2010, 6, e1000899. [CrossRef] [PubMed]

30. McGee, D.J.; Radcliff, F.J.; Mendz, G.L.; Ferrero, R.L.; Mobley, H.L. Helicobacter pylori rocF is required for arginase activity and acid protection in vitro but is not essential for colonization of mice or for urease activity. J. Bacteriol. 1999, 181, 7314-7322. [PubMed]

31. Chaturvedi, R.; Asim, M.; Lewis, N.D.; Algood, H.M.; Cover, T.L.; Kim, P.Y.; Wilson, K.T. L-arginine availability regulates inducible nitric oxide synthase-dependent host defense against Helicobacter pylori. Infect. Immun. 2007, 75, 4305-4315. [CrossRef] [PubMed]

32. Zabaleta, J.; McGee, D.J.; Zea, A.H.; Hernandez, C.P.; Rodriguez, P.C.; Sierra, R.A.; Correa, P.; Ochoa, A.C.

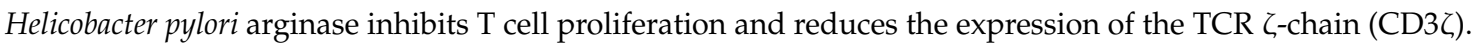
J. Immunol. 2004, 173, 586-593. [CrossRef] [PubMed]

33. Bussiere, F.I.; Chaturvedi, R.; Cheng, Y.; Gobert, A.P.; Asim, M.; Blumberg, D.R.; Xu, H.; Kim, P.Y.; Hacker, A.; Casero, R.A., Jr.; et al. Spermine causes loss of innate immune response to Helicobacter pylori by inhibition of inducible nitric-oxide synthase translation. J. Biol. Chem. 2005, 280, 2409-2412. [CrossRef] [PubMed]

34. Lahiri, A.; Das, P.; Chakravortty, D. Arginase modulates Salmonella induced nitric oxide production in RAW264.7 macrophages and is required for Salmonella pathogenesis in mice model of infection. Microbes Infect. 2008, 10, 1166-1174. [CrossRef] [PubMed]

35. Talaue, M.T.; Venketaraman, V.; Hazbon, M.H.; Peteroy-Kelly, M.; Seth, A.; Colangeli, R.; Alland, D.; Connell, N.D. Arginine homeostasis in J774.1 macrophages in the context of Mycobacterium bovis BCG infection. J. Bacteriol. 2006, 188, 4830-4840. [CrossRef] [PubMed]

36. El Kasmi, K.C.; Qualls, J.E.; Pesce, J.T.; Smith, A.M.; Thompson, R.W.; Henao-Tamayo, M.; Basaraba, R.J.; Konig, T.; Schleicher, U.; Koo, M.S.; et al. Toll-like receptor-induced arginase 1 in macrophages thwarts effective immunity against intracellular pathogens. Nat. Immunol. 2008, 9, 1399-1406. [CrossRef] [PubMed]

37. Aoki, M.P.; Guinazu, N.L.; Pellegrini, A.V.; Gotoh, T.; Masih, D.T.; Gea, S. Cruzipain, a major Trypanosoma cruzi antigen, promotes arginase-2 expression and survival of neonatal mouse cardiomyocytes. Am. J. Physiol. Cell Physiol. 2004, 286, C206-C212. [CrossRef] [PubMed]

38. Ghosh, S.; Navarathna, D.H.; Roberts, D.D.; Cooper, J.T.; Atkin, A.L.; Petro, T.M.; Nickerson, K.W. Arginine-induced germ tube formation in Candida albicans is essential for escape from murine macrophage line RAW264.7. Infect. Immun. 2009, 77, 1596-1605. [CrossRef] [PubMed]

39. Cunin, R.; Glansdorff, N.; Pierard, A.; Stalon, V. Biosynthesis and metabolism of arginine in bacteria. Microbiol. Rev. 1986, 50, 314-352. [PubMed]

40. Dong, Y.; Chen, Y.Y.; Burne, R.A. Control of expression of the arginine deiminase operon of Streptococcus gordonii by CcpA and Flp. J. Bacteriol. 2004, 186, 2511-2514. [CrossRef] [PubMed]

41. Maas, W.K. The arginine repressor of Escherichia coli. Microbiol. Rev. 1994, 58, 631-640. [PubMed]

42. Miller, C.M.; Baumberg, S.; Stockley, P.G. Operator interactions by the Bacillus subtilis arginine repressor/activator, AhrC: Novel positioning and DNA-mediated assembly of a transcriptional activator at catabolic sites. Mol. Microbiol. 1997, 26, 37-48. [CrossRef] [PubMed]

43. Griswold, A.; Chen, Y.Y.; Snyder, J.A.; Burne, R.A. Characterization of the arginine deiminase operon of Streptococcus rattus FA-1. Appl. Environ. Microbiol. 2004, 70, 1321-1327. [CrossRef] [PubMed]

44. Park, S.M.; Lu, C.D.; Abdelal, A.T. Purification and characterization of an arginine regulatory protein, ArgR, from Pseudomonas aeruginosa and its interactions with the control regions for the $\operatorname{car}$, arg $F$, and aru operons. J. Bacteriol. 1997, 179, 5309-5317. [PubMed]

45. Lu, C.D.; Winteler, H.; Abdelal, A.; Haas, D. The ArgR regulatory protein, a helper to the anaerobic regulator ANR during transcriptional activation of the $\operatorname{arcD}$ promoter in Pseudomonas aeruginosa. J. Bacteriol. 1999, 181, 2459-2464. [PubMed]

46. Fulde, M.; Willenborg, J.; de Greeff, A.; Benga, L.; Smith, H.E.; Valentin-Weigand, P.; Goethe, R. ArgR is an essential local transcriptional regulator of the $\operatorname{arc} A B C$ operon in Streptococcus suis and is crucial for biological fitness in an acidic environment. Microbiology 2011, 157, 572-582. [CrossRef] [PubMed] 
47. Park, S.M.; Lu, C.D.; Abdelal, A.T. Cloning and characterization of $\operatorname{argR}$, a gene that participates in regulation of arginine biosynthesis and catabolism in Pseudomonas aeruginosa PAO1. J. Bacteriol. 1997, 179, 5300-5308. [PubMed]

48. Zuniga, M.; Miralles Md Mdel, C.; Perez-Martinez, G. The product of $\operatorname{arcR}$, the sixth gene of the $\operatorname{arc}$ operon of Lactobacillus sakei, is essential for expression of the arginine deiminase pathway. Appl. Environ. Microbiol. 2002, 68, 6051-6058. [CrossRef] [PubMed]

49. Barcelona-Andres, B.; Marina, A.; Rubio, V. Gene structure, organization, expression, and potential regulatory mechanisms of arginine catabolism in Enterococcus faecalis. J. Bacteriol. 2002, 184, 6289-6300. [CrossRef] [PubMed]

50. Woo, P.C.; Lau, S.K.; Teng, J.L.; Que, T.L.; Yung, R.W.; Luk, W.K.; Lai, R.W.; Hui, W.T.; Wong, S.S.; Yau, H.H.; et al. Association of Laribacter hongkongensis in community-acquired gastroenteritis with travel and eating fish: A multicentre case-control study. Lancet 2004, 363, 1941-1947. [CrossRef]

51. Yuen, K.Y.; Woo, P.C.; Teng, J.L.; Leung, K.W.; Wong, M.K.; Lau, S.K. Laribacter hongkongensis gen. Nov., sp. Nov., a novel gram-negative bacterium isolated from a cirrhotic patient with bacteremia and empyema. J. Clin. Microbiol. 2001, 39, 4227-4232. [CrossRef] [PubMed]

52. Xiong, L.; Teng, J.L.; Watt, R.M.; Liu, C.; Lau, S.K.; Woo, P.C. Molecular characterization of arginine deiminase pathway in Laribacter hongkongensis and unique regulation of arginine catabolism and anabolism by multiple environmental stresses. Environ. Microbiol. 2015, 17, 4469-4483. [CrossRef] [PubMed]

53. Spiro, S. The FNR family of transcriptional regulators. Antonie van Leeuwenhoek 1994, 66, 23-36. [CrossRef] [PubMed]

54. Gamper, M.; Zimmermann, A.; Haas, D. Anaerobic regulation of transcription initiation in the $\operatorname{arcD} A B C$ operon of Pseudomonas aeruginosa. J. Bacteriol. 1991, 173, 4742-4750. [PubMed]

55. Maghnouj, A.; Abu-Bakr, A.A.; Baumberg, S.; Stalon, V.; Vander Wauven, C. Regulation of anaerobic arginine catabolism in Bacillus licheniformis by a protein of the Crp/Fnr family. FEMS Microbiol. Lett. 2000, 191, 227-234. [CrossRef] [PubMed]

56. Gruening, P.; Fulde, M.; Valentin-Weigand, P.; Goethe, R. Structure, regulation, and putative function of the arginine deiminase system of Streptococcus suis. J. Bacteriol. 2006, 188, 361-369. [CrossRef] [PubMed]

57. Eiglmeier, K.; Honore, N.; Iuchi, S.; Lin, E.C.; Cole, S.T. Molecular genetic analysis of FNR-dependent promoters. Mol. Microbiol. 1989, 3, 869-878. [CrossRef] [PubMed]

58. Spiro, S.; Guest, J.R. FNR and its role in oxygen-regulated gene expression in Escherichia coli. FEMS Microbiol. Rev. 1990, 6, 399-428. [PubMed]

59. Makhlin, J.; Kofman, T.; Borovok, I.; Kohler, C.; Engelmann, S.; Cohen, G.; Aharonowitz, Y. Staphylococcus aureus ArcR controls expression of the arginine deiminase operon. J. Bacteriol. 2007, 189, 5976-5986. [CrossRef] [PubMed]

60. Zuniga, M.; Champomier-Verges, M.; Zagorec, M.; Perez-Martinez, G. Structural and functional analysis of the gene cluster encoding the enzymes of the arginine deiminase pathway of Lactobacillus sake. J. Bacteriol. 1998, 180, 4154-4159. [PubMed]

61. Titgemeyer, F.; Hillen, W. Global control of sugar metabolism: A gram-positive solution. Antonie van Leeuwenhoek 2002, 82, 59-71. [CrossRef] [PubMed]

62. Winterhoff, N.; Goethe, R.; Gruening, P.; Rohde, M.; Kalisz, H.; Smith, H.E.; Valentin-Weigand, P. Identification and characterization of two temperature-induced surface-associated proteins of Streptococcus suis with high homologies to members of the arginine deiminase system of Streptococcus pyogenes. J. Bacteriol. 2002, 184, 6768-6776. [CrossRef] [PubMed]

63. Fernandez, M.; Zuniga, M. Amino acid catabolic pathways of lactic acid bacteria. Crit. Rev. Microbiol. 2006, 32, 155-183. [CrossRef] [PubMed]

64. Lindgren, J.K.; Thomas, V.C.; Olson, M.E.; Chaudhari, S.S.; Nuxoll, A.S.; Schaeffer, C.R.; Lindgren, K.E.; Jones, J.; Zimmerman, M.C.; Dunman, P.M.; et al. Arginine deiminase in Staphylococcus epidermidis functions to augment biofilm maturation through $\mathrm{pH}$ homeostasis. J. Bacteriol. 2014, 196, 2277-2289. [CrossRef] [PubMed]

65. Casiano-Colon, A.; Marquis, R.E. Role of the arginine deiminase system in protecting oral bacteria and an enzymatic basis for acid tolerance. Appl. Environ. Microbiol. 1988, 54, 1318-1324. [PubMed] 
66. Conte, M.P.; Petrone, G.; Di Biase, A.M.; Ammendolia, M.G.; Superti, F.; Seganti, L. Acid tolerance in Listeria monocytogenes influences invasiveness of enterocyte-like cells and macrophage-like cells. Microb. Pathog. 2000, 29, 137-144. [CrossRef] [PubMed]

67. Aderem, A.; Underhill, D.M. Mechanisms of phagocytosis in macrophages. Annu. Rev. Immunol. 1999, 17, 593-623. [CrossRef] [PubMed]

68. Vieira, O.V.; Botelho, R.J.; Grinstein, S. Phagosome maturation: Aging gracefully. Biochem. J. 2002, 366, 689-704. [CrossRef] [PubMed]

69. Vergne, I.; Chua, J.; Singh, S.B.; Deretic, V. Cell biology of Mycobacterium tuberculosis phagosome. Annu. Rev. Cell Dev. Biol. 2004, 20, 367-394. [CrossRef] [PubMed]

70. Pitt, A.; Mayorga, L.S.; Stahl, P.D.; Schwartz, A.L. Alterations in the protein composition of maturing phagosomes. J. Clin. Investig. 1992, 90, 1978-1983. [CrossRef] [PubMed]

71. Bassoe, C.F.; Bjerknes, R. Phagocytosis by human leukocytes, phagosomal pH and degradation of seven species of bacteria measured by flow cytometry. J. Med. Microbiol. 1985, 19, 115-125. [CrossRef] [PubMed]

72. O'Driscoll, B.; Gahan, C.G.; Hill, C. Adaptive acid tolerance response in Listeria monocytogenes: Isolation of an acid-tolerant mutant which demonstrates increased virulence. Appl. Environ. Microbiol. 1996, 62, 1693-1698. [PubMed]

73. Myers, B.M.; Tietz, P.S.; Tarara, J.E.; LaRusso, N.F. Dynamic measurements of the acute and chronic effects of lysosomotropic agents on hepatocyte lysosomal pH using flow cytometry. Hepatology 1995, 22, 1519-1526. [PubMed]

74. Ohkuma, S.; Poole, B. Fluorescence probe measurement of the intralysosomal $\mathrm{pH}$ in living cells and the perturbation of $\mathrm{pH}$ by various agents. Proc. Natl. Acad. Sci. USA 1978, 75, 3327-3331. [CrossRef] [PubMed]

75. Flannagan, R.S.; Cosio, G.; Grinstein, S. Antimicrobial mechanisms of phagocytes and bacterial evasion strategies. Nat. Rev. Microbiol. 2009, 7, 355-366. [CrossRef] [PubMed]

76. Alderton, W.K.; Cooper, C.E.; Knowles, R.G. Nitric oxide synthases: Structure, function and inhibition. Biochem. J. 2001, 357, 593-615. [CrossRef] [PubMed]

77. Fang, F.C. Antimicrobial reactive oxygen and nitrogen species: Concepts and controversies. Nat. Rev. Microbiol. 2004, 2, 820-832. [CrossRef] [PubMed]

78. Mori, M.; Gotoh, T. Arginine metabolic enzymes, nitric oxide and infection. J. Nutr. 2004, 134, 2820 S-2825S. [PubMed]

79. Yu, H.H.; Wu, F.L.; Lin, S.E.; Shen, L.J. Recombinant arginine deiminase reduces inducible nitric oxide synthase iNOS-mediated neurotoxicity in a coculture of neurons and microglia. J. Neurosci. Res. 2008, 86, 2963-2972. [CrossRef] [PubMed]

80. Lee, E.J.; Pontes, M.H.; Groisman, E.A. A bacterial virulence protein promotes pathogenicity by inhibiting the bacterium's own F1Fo ATP synthase. Cell 2013, 154, 146-156. [CrossRef] [PubMed]

81. Xu, L.; Shen, X.; Bryan, A.; Banga, S.; Swanson, M.S.; Luo, Z.Q. Inhibition of host vacuolar $\mathrm{H}^{+}$-ATPase activity by a Legionella pneumophila effector. PLoS Pathog. 2010, 6, e1000822. [CrossRef] [PubMed]

82. Wong, D.; Bach, H.; Sun, J.; Hmama, Z.; Av-Gay, Y. Mycobacterium tuberculosis protein tyrosine phosphatase (PtpA) excludes host vacuolar-H ${ }^{+}$-ATPase to inhibit phagosome acidification. Proc. Natl. Acad. Sci. USA 2011, 108, 19371-19376. [CrossRef] [PubMed]

83. Cotter, P.D.; Gahan, C.G.; Hill, C. Analysis of the role of the Listeria monocytogenes F0F1-ATPase operon in the acid tolerance response. Int. J. Food Microbiol. 2000, 60, 137-146. [CrossRef]

84. Hanahan, D.; Weinberg, R.A. Hallmarks of cancer: The next generation. Cell 2011, 144, 646-674. [CrossRef] [PubMed]

85. Savaraj, N.; You, M.; Wu, C.; Wangpaichitr, M.; Kuo, M.T.; Feun, L.G. Arginine deprivation, autophagy, apoptosis (AAA) for the treatment of melanoma. Curr. Mol. Med. 2010, 10, 405-412. [CrossRef] [PubMed]

86. Changou, C.A.; Chen, Y.R.; Xing, L.; Yen, Y.; Chuang, F.Y.; Cheng, R.H.; Bold, R.J.; Ann, D.K.; Kung, H.J. Arginine starvation-associated atypical cellular death involves mitochondrial dysfunction, nuclear DNA leakage, and chromatin autophagy. Proc. Natl. Acad. Sci. USA 2014, 111, 14147-14152. [CrossRef] [PubMed]

87. Tennant, D.A.; Duran, R.V.; Gottlieb, E. Targeting metabolic transformation for cancer therapy. Nat. Rev. Cancer 2010, 10, 267-277. [CrossRef] [PubMed]

88. Wheatley, D.N.; Campbell, E. Arginine catabolism, liver extracts and cancer. Pathol. Oncol. Res. 2002, 8, 18-25. [CrossRef] [PubMed] 
89. Qiu, F.; Chen, Y.R.; Liu, X.; Chu, C.Y.; Shen, L.J.; Xu, J.; Gaur, S.; Forman, H.J.; Zhang, H.; Zheng, S.; et al . Arginine starvation impairs mitochondrial respiratory function in ASS1-deficient breast cancer cells. Sci. Signal. 2014, 7. [CrossRef] [PubMed]

90. Dillon, B.J.; Prieto, V.G.; Curley, S.A.; Ensor, C.M.; Holtsberg, F.W.; Bomalaski, J.S.; Clark, M.A. Incidence and distribution of argininosuccinate synthetase deficiency in human cancers: A method for identifying cancers sensitive to arginine deprivation. Cancer 2004, 100, 826-833. [CrossRef] [PubMed]

91. Bowles, T.L.; Kim, R.; Galante, J.; Parsons, C.M.; Virudachalam, S.; Kung, H.J.; Bold, R.J. Pancreatic cancer cell lines deficient in argininosuccinate synthetase are sensitive to arginine deprivation by arginine deiminase. Int. J. Cancer 2008, 123, 1950-1955. [CrossRef] [PubMed]

92. Scott, L.; Lamb, J.; Smith, S.; Wheatley, D.N. Single amino acid (arginine) deprivation: Rapid and selective death of cultured transformed and malignant cells. Br. J. Cancer 2000, 83, 800-810. [CrossRef] [PubMed]

93. Liu, J.; Ma, J.; Wu, Z.; Li, W.; Zhang, D.; Han, L.; Wang, F.; Reindl, K.M.; Wu, E.; Ma, Q. Arginine deiminase augments the chemosensitivity of argininosuccinate synthetase-deficient pancreatic cancer cells to gemcitabine via inhibition of NF-kB signaling. BMC Cancer 2014, 14. [CrossRef] [PubMed]

94. Miraki-Moud, F.; Ghazaly, E.; Ariza-McNaughton, L.; Hodby, K.A.; Clear, A.; Anjos-Afonso, F.; Liapis, K.; Grantham, M.; Sohrabi, F.; Cavenagh, J.; et al. Arginine deprivation using pegylated arginine deiminase has activity against primary acute myeloid leukemia cells in vivo. Blood 2015, 125, 4060-4068. [CrossRef] [PubMed]

95. Savaraj, N.; Wu, C.; Kuo, M.T.; You, M.; Wangpaichitr, M.; Robles, C.; Spector, S.; Feun, L. The relationship of arginine deprivation, argininosuccinate synthetase and cell death in melanoma. Drug Target Insights 2007, 2, 119-128. [PubMed]

96. Lam, T.L.; Wong, G.K.; Chow, H.Y.; Chong, H.C.; Chow, T.L.; Kwok, S.Y.; Cheng, P.N.; Wheatley, D.N.; Lo, W.H.; Leung, Y.C. Recombinant human arginase inhibits the in vitro and in vivo proliferation of human melanoma by inducing cell cycle arrest and apoptosis. Pigment Cell Melanoma Res. 2011, 24, 366-376. [CrossRef] [PubMed]

97. Sugimura, K.; Ohno, T.; Kusuyama, T.; Azuma, I. High sensitivity of human melanoma cell lines to the growth inhibitory activity of mycoplasmal arginine deiminase in vitro. Melanoma Res. 1992, 2, 191-196. [CrossRef] [PubMed]

98. Ni, Y.; Schwaneberg, U.; Sun, Z.H. Arginine deiminase, a potential anti-tumor drug. Cancer Lett. 2008, 261, 1-11. [CrossRef] [PubMed]

99. Yoon, J.K.; Frankel, A.E.; Feun, L.G.; Ekmekcioglu, S.; Kim, K.B. Arginine deprivation therapy for malignant melanoma. Clin. Pharmacol. 2013, 5, 11-19. [PubMed]

100. Ensor, C.M.; Holtsberg, F.W.; Bomalaski, J.S.; Clark, M.A. Pegylated arginine deiminase (ADI-SS $\mathrm{PEG}_{20,000 \mathrm{mw}}$ ) inhibits human melanomas and hepatocellular carcinomas in vitro and in vivo. Cancer Res. 2002, 62, 5443-5450. [PubMed]

101. Kim, R.H.; Bold, R.J.; Kung, H.J. ADI, autophagy and apoptosis: Metabolic stress as a therapeutic option for prostate cancer. Autophagy 2009, 5, 567-568. [PubMed]

102. Kim, R.H.; Coates, J.M.; Bowles, T.L.; McNerney, G.P.; Sutcliffe, J.; Jung, J.U.; Gandour-Edwards, R.; Chuang, F.Y.; Bold, R.J.; Kung, H.J. Arginine deiminase as a novel therapy for prostate cancer induces autophagy and caspase-independent apoptosis. Cancer Res. 2009, 69, 700-708. [CrossRef] [PubMed]

103. Zeng, X.; Li, Y.; Fan, J.; Zhao, H.; Xian, Z.; Sun, Y.; Wang, Z.; Wang, S.; Zhang, G.; Ju, D. Recombinant human arginase induced caspase-dependent apoptosis and autophagy in non-hodgkin's lymphoma cells. Cell Death Dis. 2013, 4. [CrossRef] [PubMed]

104. Delage, B.; Luong, P.; Maharaj, L.; O'Riain, C.; Syed, N.; Crook, T.; Hatzimichael, E.; Papoudou-Bai, A.; Mitchell, T.J.; Whittaker, S.J.; et al. Promoter methylation of argininosuccinate synthetase-1 sensitises lymphomas to arginine deiminase treatment, autophagy and caspase-dependent apoptosis. Cell Death Dis. 2012, 3. [CrossRef] [PubMed]

105. Izzo, F.; Marra, P.; Beneduce, G.; Castello, G.; Vallone, P.; De Rosa, V.; Cremona, F.; Ensor, C.M.; Holtsberg, F.W.; Bomalaski, J.S.; et al. Pegylated arginine deiminase treatment of patients with unresectable hepatocellular carcinoma: Results from phase I/II studies. J. Clin. Oncol. 2004, 22, 1815-1822. [CrossRef] [PubMed] 
106. Glazer, E.S.; Piccirillo, M.; Albino, V.; Di Giacomo, R.; Palaia, R.; Mastro, A.A.; Beneduce, G.; Castello, G.; De Rosa, V.; Petrillo, A.; et al. Phase II study of pegylated arginine deiminase for nonresectable and metastatic hepatocellular carcinoma. J. Clin. Oncol. 2010, 28, 2220-2226. [CrossRef] [PubMed]

107. McAlpine, J.A.; Lu, H.T.; Wu, K.C.; Knowles, S.K.; Thomson, J.A. Down-regulation of argininosuccinate synthetase is associated with cisplatin resistance in hepatocellular carcinoma cell lines: Implications for pegylated arginine deiminase combination therapy. BMC Cancer 2014, 14. [CrossRef] [PubMed]

108. Daylami, R.; Muilenburg, D.J.; Virudachalam, S.; Bold, R.J. Pegylated arginine deiminase synergistically increases the cytotoxicity of gemcitabine in human pancreatic cancer. J. Exp. Clin. Cancer Res. 2014, 33. [CrossRef] [PubMed]

109. Tokunaga, C.; Yoshino, K.; Yonezawa, K. mTOR integrates amino acid- and energy-sensing pathways. Biochem. Biophys. Res. Commun. 2004, 313, 443-446. [CrossRef] [PubMed]

110. Mussai, F.; Egan, S.; Higginbotham-Jones, J.; Perry, T.; Beggs, A.; Odintsova, E.; Loke, J.; Pratt, G.; U, K.P.; Lo, A.; et al. Arginine dependence of acute myeloid leukemia blast proliferation: A novel therapeutic target. Blood 2015, 125, 2386-2396. [CrossRef] [PubMed]

111. Zwaan, C.M.; Kolb, E.A.; Reinhardt, D.; Abrahamsson, J.; Adachi, S.; Aplenc, R.; De Bont, E.S.; De Moerloose, B.; Dworzak, M.; Gibson, B.E.; et al. Collaborative efforts driving progress in pediatric acute myeloid leukemia. J. Clin. Oncol. 2015, 33, 2949-2962. [CrossRef] [PubMed]

112. Syed, N.; Langer, J.; Janczar, K.; Singh, P.; Lo Nigro, C.; Lattanzio, L.; Coley, H.M.; Hatzimichael, E.; Bomalaski, J.; Szlosarek, P.; et al. Epigenetic status of argininosuccinate synthetase and argininosuccinate lyase modulates autophagy and cell death in glioblastoma. Cell Death Dis. 2013, 4. [CrossRef] [PubMed]

113. Szlosarek, P.W.; Klabatsa, A.; Pallaska, A.; Sheaff, M.; Smith, P.; Crook, T.; Grimshaw, M.J.; Steele, J.P.; Rudd, R.M.; Balkwill, F.R.; et al. In vivo loss of expression of argininosuccinate synthetase in malignant pleural mesothelioma is a biomarker for susceptibility to arginine depletion. Clin. Cancer Res. 2006, 12, 7126-7131. [CrossRef] [PubMed]

114. Yoon, C.Y.; Shim, Y.J.; Kim, E.H.; Lee, J.H.; Won, N.H.; Kim, J.H.; Park, I.S.; Yoon, D.K.; Min, B.H. Renal cell carcinoma does not express argininosuccinate synthetase and is highly sensitive to arginine deprivation via arginine deiminase. Int. J. Cancer 2007, 120, 897-905. [CrossRef] [PubMed]

115. Kelly, M.P.; Jungbluth, A.A.; Wu, B.W.; Bomalaski, J.; Old, L.J.; Ritter, G. Arginine deiminase PEG20 inhibits growth of small cell lung cancers lacking expression of argininosuccinate synthetase. Br. J. Cancer 2012, 106, 324-332. [CrossRef] [PubMed]

116. Kuhn, N.J.; Talbot, J.; Ward, S. pH-sensitive control of arginase by $\mathrm{Mn}(\mathrm{II})$ ions at submicromolar concentrations. Arch. Biochem. Biophys. 1991, 286, 217-221. [CrossRef]

117. Cheng, P.N.; Lam, T.L.; Lam, W.M.; Tsui, S.M.; Cheng, A.W.; Lo, W.H.; Leung, Y.C. Pegylated recombinant human arginase (rhArg-peg (, $000 \mathrm{mw}$ ) inhibits the in vitro and in vivo proliferation of human hepatocellular carcinoma through arginine depletion. Cancer Res. 2007, 67, 309-317. [CrossRef] [PubMed]

118. Stone, E.M.; Glazer, E.S.; Chantranupong, L.; Cherukuri, P.; Breece, R.M.; Tierney, D.L.; Curley, S.A.; Iverson, B.L.; Georgiou, G. Replacing $\mathrm{Mn}^{2+}$ with $\mathrm{Co}^{2+}$ in human arginase I enhances cytotoxicity toward L-arginine auxotrophic cancer cell lines. ACS Chem. Biol. 2010, 5, 333-342. [CrossRef] [PubMed]

119. Li, L.; Wang, Y.; Chen, J.; Cheng, B.; Hu, J.; Zhou, Y.; Gao, X.; Gao, L.; Mei, X.; Sun, M.; et al. An engineered arginase FC protein inhibits tumor growth in vitro and in vivo. Evid. Based Complement. Alternat. Med. 2013, 2013. [CrossRef] [PubMed]

120. Wheatley, D.N. Arginine deprivation and metabolomics: Important aspects of intermediary metabolism in relation to the differential sensitivity of normal and tumour cells. Semin. Cancer Biol. 2005, 15, 247-253. [CrossRef] [PubMed]

121. Miyazaki, K.; Takaku, H.; Umeda, M.; Fujita, T.; Huang, W.D.; Kimura, T.; Yamashita, J.; Horio, T. Potent growth inhibition of human tumor cells in culture by arginine deiminase purified from a culture medium of a Mycoplasma-infected cell line. Cancer Res. 1990, 50, 4522-4527. [PubMed]

122. Takaku, H.; Takase, M.; Abe, S.; Hayashi, H.; Miyazaki, K. In vivo anti-tumor activity of arginine deiminase purified from Mycoplasma arginini. Int. J. Cancer 1992, 51, 244-249. [CrossRef] [PubMed]

123. Holtsberg, F.W.; Ensor, C.M.; Steiner, M.R.; Bomalaski, J.S.; Clark, M.A. Poly(ethylene glycol) (PEG) conjugated arginine deiminase: Effects of PEG formulations on its pharmacological properties. J. Control. Release 2002, 80, 259-271. [CrossRef] 
124. Dillon, B.J.; Holtsberg, F.W.; Ensor, C.M.; Bomalaski, J.S.; Clark, M.A. Biochemical characterization of the arginine degrading enzymes arginase and arginine deiminase and their effect on nitric oxide production. Med. Sci. Monit. 2002, 8, Br248-Br253. [PubMed]

125. Feun, L.; Savaraj, N. Pegylated arginine deiminase: A novel anticancer enzyme agent. Expert Opin. Investig. Drugs 2006, 15, 815-822. [CrossRef] [PubMed]

126. Lin, S.E.; Wu, F.L.; Wei, M.F.; Shen, L.J. Depletion of arginine by recombinant arginine deiminase induces nNOS-activated neurotoxicity in neuroblastoma cells. Biomed. Res. Int. 2014, 2014. [CrossRef] [PubMed]

127. Szlosarek, P.W.; Luong, P.; Phillips, M.M.; Baccarini, M.; Stephen, E.; Szyszko, T.; Sheaff, M.T.; Avril, N. Metabolic response to pegylated arginine deiminase in mesothelioma with promoter methylation of argininosuccinate synthetase. J. Clin. Oncol. 2013, 31, e111-e113. [CrossRef] [PubMed]

128. Delage, B.; Fennell, D.A.; Nicholson, L.; McNeish, I.; Lemoine, N.R.; Crook, T.; Szlosarek, P.W. Arginine deprivation and argininosuccinate synthetase expression in the treatment of cancer. Int. J. Cancer 2010, 126, 2762-2772. [CrossRef] [PubMed]

129. Huang, J.; Brumell, J.H. Bacteria-autophagy interplay: A battle for survival. Nat. Rev. Microbiol. 2014, 12, 101-114. [CrossRef] [PubMed]

130. Vellai, T.; Toth, M.L.; Kovacs, A.L. Janus-faced autophagy: A dual role of cellular self-eating in neurodegeneration? Autophagy 2007, 3, 461-463. [CrossRef] [PubMed]

131. Maiuri, M.C.; Zalckvar, E.; Kimchi, A.; Kroemer, G. Self-eating and self-killing: Crosstalk between autophagy and apoptosis. Nat. Rev. Mol. Cell Biol. 2007, 8, 741-752. [CrossRef] [PubMed]

132. Jin, S.; White, E. Role of autophagy in cancer: Management of metabolic stress. Autophagy 2007, 3, $28-31$. [CrossRef] [PubMed]

133. Proud, C.G. mTOR-mediated regulation of translation factors by amino acids. Biochem. Biophys. Res. Commun. 2004, 313, 429-436. [CrossRef] [PubMed]

134. Sarbassov, D.D.; Ali, S.M.; Sabatini, D.M. Growing roles for the mTOR pathway. Curr. Opin. Cell Biol. 2005, 17, 596-603. [CrossRef] [PubMed]

135. Wang, J.; Whiteman, M.W.; Lian, H.; Wang, G.; Singh, A.; Huang, D.; Denmark, T. A non-canonical MEK/ERK signaling pathway regulates autophagy via regulating Beclin 1. J. Biol. Chem. 2009, 284, 21412-21424. [CrossRef] [PubMed]

136. Gong, H.; Zolzer, F.; von Recklinghausen, G.; Havers, W.; Schweigerer, L. Arginine deiminase inhibits proliferation of human leukemia cells more potently than asparaginase by inducing cell cycle arrest and apoptosis. Leukemia 2000, 14, 826-829. [CrossRef] [PubMed]

137. Szlosarek, P.W. Arginine deprivation and autophagic cell death in cancer. Proc. Natl. Acad. Sci. USA 2014, 111, 14015-14016. [CrossRef] [PubMed]

138. Ouyang, L.; Shi, Z.; Zhao, S.; Wang, F.T.; Zhou, T.T.; Liu, B.; Bao, J.K. Programmed cell death pathways in cancer: A review of apoptosis, autophagy and programmed necrosis. Cell Prolif. 2012, 45, 487-498. [CrossRef] [PubMed]

(C) 2016 by the authors; licensee MDPI, Basel, Switzerland. This article is an open access article distributed under the terms and conditions of the Creative Commons by Attribution (CC-BY) license (http://creativecommons.org/licenses/by/4.0/). 